\title{
Morphological features of the flower of Symphoricarpos species (Caprifoliaceae) introduced to Ukraine
}

\section{Olena Bulakh}

M.G. Kholodny Institute of Botany, National Academy of Sciences of Ukraine, Tereschenkivska str. 2, 01004 Kyiv, Ukraine; anemone@ukr.net

Received: 02.10.2020 | Accepted: 12.12 .2020 | Published: 30.12 .2020

\begin{abstract}
With the help of light and scanning electron microscopy, the features of inflorescences and flowers of six species of the genus Symphoricarpos introduced to Ukraine were studied, and the peculiarities of their structure were specified. Morphological peculiarities of the calyx, corolla, stamens, and style, differentiating S. albus (including S. racemosus and S. rivularis), S. hesperius, S. mollis, S. occidentalis, S. orbiculatus, and S. oreophilus var. utahensis, were determined. The obtained data are important for identification of the species and taxonomy of the genus Symphoricarpos. In particular, the results of our study showed that flowers of S. racemosus, S. rivularis, and S. albus share common features and this supports their synonymy under the name S. albus. Other five Symphoricarpos species showed differences in their floral morphology.

Among the important features for identification of Symphoricarpos species introduced to Ukraine, which were not mentioned in available literature sources we can list: the number of flowers in the inflorescence, features of pedicels, shape and features of bracts pubescence, shape of calyx teeth and their pubescence, presence or absence of corolla tube convexity, presence of ovoid projection of anther's connective, and size of all the floral elements.

Symphoricarpos oreophilus var. utahensis has unique features of floral morphology. Its single flowers located in the axis of the leaves on the pendent pubescent pedicels; the calyx is elongated, fusiform; the corolla is narrowly tubular, without a convex at the base; the stamens are shorter than the corolla tubule or rarely of the same length, with a clear ovoid projection on the apex.
\end{abstract}

Keywords: Symphoricarpos, morphology, inflorescence, flower, diagnostic features

\section{Introduction}

The genus Symphoricarpos Duhamel includes 9 to 15 species, and belongs to the family Caprifoliaceae Juss. of the order Dipsacales Juss. ex Bercht. \& J. Presl (Takhtajan, 1997, 2009). Today numerous molecularphylogenetic studies are actively performed on different representatives of this order. Thereafter, active discussion regarding the evolution of the reproductive organs of these representatives is ongoing (Bell et al., 2001; Zhang et al., 2003; Theis et al., 2008).
Dipsacales demonstrates the number of evolutionary changes that may be of interest in understanding the morphology of flower in general. The modern representatives of this order have from five (the most common) to three lobes of corolla, and the number of stamens vary from one to ten (most often there are five or four stamens per flower). The ancestor of the recent Caprifoliaceae is still unknown. Modern representatives of the family have funnel-shaped or campanulate flowers with four or five lobes, small calyx, four or five 
stamens, elongated style, and capitate or lobed stigma. Probably before that, they were slightly different, and had symmetrical flowers with large calyxes, tubular corollas with five lobes at the apex, five stamens, elongated styles, and capitate stigmas. Among some species of the genus Symphoricarpos, the reduction to four lobes of the corolla and four stamens happened. In general, five types of flower shape were suggested for Caprifoliaceae, and the genus Symphoricarpos has been classified as those having radially symmetrical flowers (Roels \& Smets, 1996; Donoghue et al., 2003; Zhang et al., 2003; Howarth \& Donoghue, 2005; Hauser, 2007; Theis et al., 2008).

The genus Symphoricarpos includes shrubs with multicolored fruits, and therefore these plants are often used as ornamental. The several species of this genus are widely cultivated in botanical gardens and parks, particularly in Ukraine. The natural area of distribution of the genus spread from North America to Mexico (Leroy \& Stinchfield Ferris, 1960; Wood, 1965; Hitchcock \& Cronquist, 1973; Evans, 1974; Moss, 1983; Welsh et al., 1987, 1993; Kartesz, 1994; Gilbert, 1995; McWilliams, 2000; Sell \& Murrell, 2006). One species is considered endemic to China (Yang et al., 2011).

According to Mosyakin \& Fedoronhuk (1999), S. albus (L.) S.F. Blake (= S. racemosus Michx. and S. rivularis Suksdorf.) is widespread in Ukraine as an ornamental plant. While S. occidentalis Hook. and S. orbiculatus Moench. are rarely applied for landscaping in gardens and parks of Ukraine (Barbarych, 1961). Some other species of the genus (i.e., S. hesperius G.N. Jones, S. mollis Nutt., S. oreophilus Gray) were also introduced to Ukraine, and their specimens are stored at the herbarium of the M.M. Gryshko National Botanical Garden of the NAS of Ukraine.

Due to the wide introduction of Symphoricarpos in Ukraine, it is important to study their morphological features in more details, with special emphasis on the structure of their reproductive organs and identify taxonomic diagnostic features. However, the literature provides little information on their morphological features of inflorescence, flower, and fruits of Symphoricarpos species, which are represented in some local floras (Leroy \& Stinchfield Ferris, 1960; Barbarych, 1961; Welsh et al., 1987, 1993; Gilbert, 1995;
McWilliams, 2000; Sell \& Murrell, 2006; Yang, 2011).

Hence, we decided to clarify the features of the flower of Symphoricarpos introduced to Ukraine, and identify additional features, which could be applied in the taxonomy of the genus.

\section{Material and methods}

The material from the National Herbarium of the M.G. Kholodny Institute of Botany of the National Academy of Sciences of Ukraine (KW) and the Herbarium of the M.M Gryshko National Botanical Garden of the National Academy of Sciences of Ukraine (KWHA) has been used. The citations are provided accordingly to the original text of the labels. The flowers of 18 specimens of six Symphoricarpos species listed below were investigated. Macromorphological features were analyzed for all flowers present on the herbarium voucher (in average 3-5 flowers per voucher). For the micromorphological analysis, from 1-2 (S. hesperius, S. mollis, S. oreophilus) to 3-5 flowers were sampled (S. albus, S. occidentalis, S. orbiculatus) depending on the number of available vouchers. Macromorphological features of the flowers were studied using MBS-9 binocular microscope. Floral elements were measured using AxioVision Rel. 4.8 software. For scanning electron microscopy (SEM, JSM$6060 \mathrm{LA})$ the specimens were fixed on the brass table, then these samples were goldcoated. The descriptions of floral elements follows terminology of Fedorov \& Artiushenko (1975) and Zyman et al. (2004, 2011).

\section{Samples examined}

Symphoricarpos albus: 1. Chernihiv region, Ichnyansky district, Trostyanets Dendrological Park, arboretum, quarter 29, № 5716, planted in the spring of 1964, 9.VI.1975, Without author (KWHA); 2. Academy of Sciences of the Ukrainian SSR, Dendrological park "Sofievka", Cherkasy region, Uman town, 25.IX.1970, Leg. Melnik V.D., Det. Tulupiy G.G. (KWHA); 3. Ukraine, Sumy Region, Sumy city, Red Square, 4.VIII.1969, Litvinenko (KW); 4. Ukraine, Khmelnytsky region, Netishin town, 8 Enerhetykiv str., V.2004, 090270, Hubar (KWHA); 5. Sumy region, Sumy district, Kianyanitsa village, Kianyansky Arboretum, 16.VIII.1970, Litvinenko (KW); 6. Chernivtsi region, Storozhynets district, Krasnoilsk village, farm [...], bushes at the edge of the beech forest on the slope of Seretel river, 20.VI.1947, Kosic (KW); 7. Herbarium Shevchenko 
Chernihiv Pedagogical Universitatus, Chernihiv (Ukraine), Chernihiv city, CHPP Agrobiostation, Arboretum, 08.07.2010, Pototska O.S. (KWHA); 8. USSR, Kiev city, CRBG Academy of Sciences of the Ukrainian SSR, "System of Higher Plants" section, 13.IX.1974, Leg. Smyk G.K., Det. Sarycheva Z.A. (KWHA); 9. USSR, Bila Tserkva city, Alexandria Arboretum, Frumitsetum collection sector, seedlings obtained from the nursery of the Alexandria Arboretum in 1960, 19.VI.1969, Grysyuk (KWHA).

Symphoricarpos hesperius: 1. Herbarium of the Trostyanets Dendrological Park, Academy of Sciences of the Ukrainian SSR. Chernihiv region, Ichnyansky district, Arboretum, quarter 29, № 1554, origin: Tashkent city, 1958, obtained under the name Symphoricarpos hesperius G.N. Jones, 9.VI.1975 (KWHA).

Symphoricarpos mollis: 1. Herbarium of the Trostyanets Dendrological Park, Academy of Sciences of the Ukrainian SSR. Chernihiv region, Ichnyansky district, Arboretum, quarter 29, № 1735, origin: Leningrad city, 1958, obtained under the name Symphoricarpos mollis Nutt., 9.VI.1975 (KWHA).

Symphoricarpos occidentalis: 1. [Ukraine] Sumy region, Sumy district, Verteyevka village, the park of agricultural college, 18.IV.1970, Litvinenko (KW); 2. USSR, Poltava region, Globinsky district, Ustimovka Dendropark, building № 3, origin unknown, 14.06.1960, Chapinoga (KWHA); 3. Herbarium of the Trostyanets Dendrological Park, Academy of Sciences of the Ukrainian SSR. Chernihiv region, Ichnyansky district, Arboretum, quarter 29, Nr. 2838, the origin is city Voronezh, 1959, obtained under the name Symphoricarpos occidentalis Hook., 9.VI.1975 (KWHA); 4. Herbarium of the Trostyanets Dendrological Park, Academy of Sciences of the Ukrainian SSR. Chernihiv region, Ichnyansky district, Arboretum, quarter 29, № 366, the origin is city Dnipropetrovsk, 1958, obtained under the name Symphoricarpos occidentalis Hook., 9.VI.1975 (KWHA).

Symphoricarpos oreophilus var. utahensis: 1. Plant of Nevada. Humboldt Co.: Pine Forest Range, Lonard Creek drainage. Twp. 43 N., R. 29 E. Elevation about 7,000 feet. Shrub growing in rocks of outcrop. Noel H. Holmgren, James L. Reveal, 1229, July 1, 1964 (KW).

Symphoricarpos orbiculatus: 1. Herbarium of the Trostyanets Dendrological Park, Academy of Sciences of the Ukrainian SSR, Chernihiv region, Ichnyansky district, Arboretum, quarter 43, № 2977, the origin is city Minsk, $1958,17$. VI.1975 (KWHA); 2. Academy of Sciences of the USSR, Sofiyivka Dendropark, Cherkasy region, Uman city, Sofiyivka, Grekov Yar, 8 VIII 1970, Leg. Melnik V.D., Det. Tulupiy G.G. (KWHA); 3. [Herbarium of Lugansk Taras Shevchenko National Pedagogical University] Lugansk city, ALNDS Dendropark, 24.06.2006, Philimonova (KWHA).

Symphoricarpos racemosus: 1. Société Françaice, 1921. Exsicc. Ch. Duffour. Cóte-d'or: Flavigny. Plante américaricaine cultivée et naturolisée. 20 juin 1921, 3791 G.Desplantes(KW);2. [Russia]Voronezh province, Valuysky district, gardens [SI. Uralov], 18.VII.1915, Kotov (KW); 3. [Symphoricarpos racemosa Michx.] USSR, Zakarpattia region, Uzhgorod, State Fruit Nursery, 22.VII.1947, ex. Botanical Garden of the Academy of Sciences of the USSR, Det. Sokolovsky (KWHA); 4. [Symphoricarpos racemosa Michx.] USSR, Zakarpattia region, Rakhiv, VII.1947, ex.
Botanical Garden of the Academy of Sciences of the Ukrainian SSR, Det. Sokolovsky (KWHA).

Symphoricarpos rivularis: 1. [Herbarium of Luhansk the Taras Shevchenko National Pedagogical University] Luhansk city, territory of LNPU campus, 18.07.2006, Philimonova (KWHA).

\section{Results and discussion}

Flowers of Symphoricarpos are actinomorphic, symmetrical, and small (about $10 \mathrm{~mm}$ long), with short ribbed pedicels (S. albus, S. orbiculatus, S. racemosus, S. rivularis) or pedicels without ribs (S. hesperius, S. mollis), grouped in short racemes, located in the axils of the upper leaves on the apical or lateral branches. At the base of the ovary of each flower of all studied species there are two opposite, small (0.5-1.5 mm long), ovate or triangular bracteoles, which are coalescent at the base (in S. oreophilus var. utahensis bracteoles are free), pubescent along the edges, or glabrous (S. hesperius, S. mollis, and S. occidentalis) (Tables $1 \& 2)$.

The calyx is fused, subspherical (S. albus), obovoid (S. hesperius, S. occidentalis), oval (S. mollis, S. orbiculatus, S. racemosus, S. rivularis), or fusiform (S. oreophilus var. utahensis). On the apex of the calyx there are (4-) 5 small (0.5-1.0 mm long), triangular or ovoid teeth, which are glabrous (S. hesperius, S. mollis, S. occidentalis, and S. racemosus), or slightly pubescent at the edges (S albus, $\mathrm{S}$. oreophilus var. utahensis, $\mathrm{S}$. rivularis). S. orbiculatus also has a bundle of hairs at the apex of the calyx teeth (Fig. 1; Tables $1 \& 2$ ).

The corolla is $5-8 \mathrm{~mm}$ long on average, spine-lobed, with a straight campanulate tube and a bend. The tube is convex at the base on one side (crescentshape in S. hesperius), glabrous outside, pubescent, with ribbonlike hairs inside. The bend of the corolla of the studied species is $3-6 \mathrm{~mm}$ in diameter and divided into five oval (broadly oval) or ovoid (narrowly ovoid) lobes. The apices of the lobes are orbicular (S. hesperius, S. mollis, S. orbiculatus), obtuse (S. albus, S. oreophilus var. utahensis), or acute (S. racemosus, S. rivularis) (Figs. 2 \& 3; Tables $1 \& 2$ ).

There are (4-) 5 stamens with thin filaments and ellipsoidal anthers attached to the filaments in the middle; the length of the anthers is $1.0-1.5 \mathrm{~mm}$. The stamens in most 

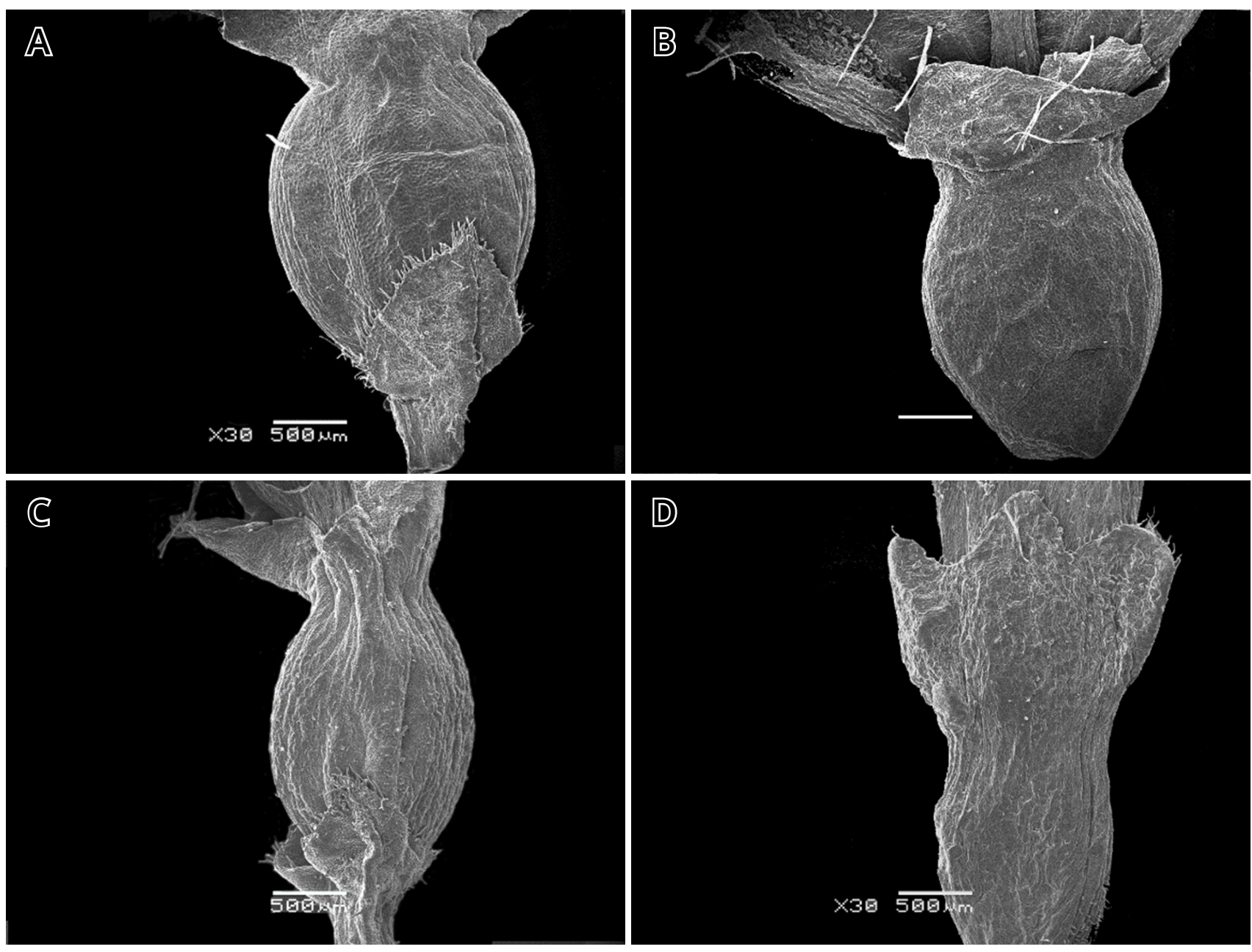

Figure 1. Shape of the calyx (SEM): A - Symphoricarpos albus (subspherical); B - S. hesperius (obovoid); C - S. orbiculatus (oval); D - S. oreophilus var. utahensis (spindle-shaped).

of the studied species are located in the tube of corolla; they are mostly equal in length or slightly longer than the corolla. However, S. occidentalis have stamens longer than the corolla, while the stamens of S. oreophilus var. utahensis are shorter than the corolla. We noted that the stamens of the studied Symphoricarpos species have an ovoid projection of the connective above the anthers; the length of this projection is about $0.5 \mathrm{~mm}$ (Fig. 4). The presence of such projections has been recently reported for Linnaea borealis $\mathrm{L}$. (Tsymbaliuk et al., 2018).

The pistil has a thin style, which is usually shorter than the corolla. However, in S. occidentalis column is longer than the corolla, and in S. racemosus it is equal to the corolla. In all the investigated species, the stigma is capitate, about $0.5 \mathrm{~mm}$ in diameter (Tables $1 \& 2$ ).

The results of our study showed that $\mathrm{S}$. racemosus and $\mathrm{S}$. rivularis, which are considered phylogenetically close to S. albus (Leroy \& Stinchfield Ferris, 1960; Hitchcock \& Cronquist, 1973; Evans, 1974; Moss, 1983; Gilbert, 1995; McWilliams, 2000) share many common features of floral organization. This, in particular, supports their synonymy under the name S. albus (Gilbert, 1995).

Two close species (S. orbiculatus and S. occidentalis) showed some differences in their floral morphology. In particular, S. orbiculatus have short pedicels, whereas in S. occidentalis the flowers are sessile. S. orbiculatus bracteoles are sparsely pubescent, with small subulate hairs along the edges, while S. occidentalis bracteoles are glabrous. Each teeth of calyx in S. orbiculatus have a bundle of subulate hairs at the apex, whereas in S. occidentalis they are glabrous. The corolla lobes of S. orbiculatus are oval, with rounded apices, equal to $1 / 3$ of the corolla length; these lobes in S. occidentalis are broadly oval, with acute apices, equal to 


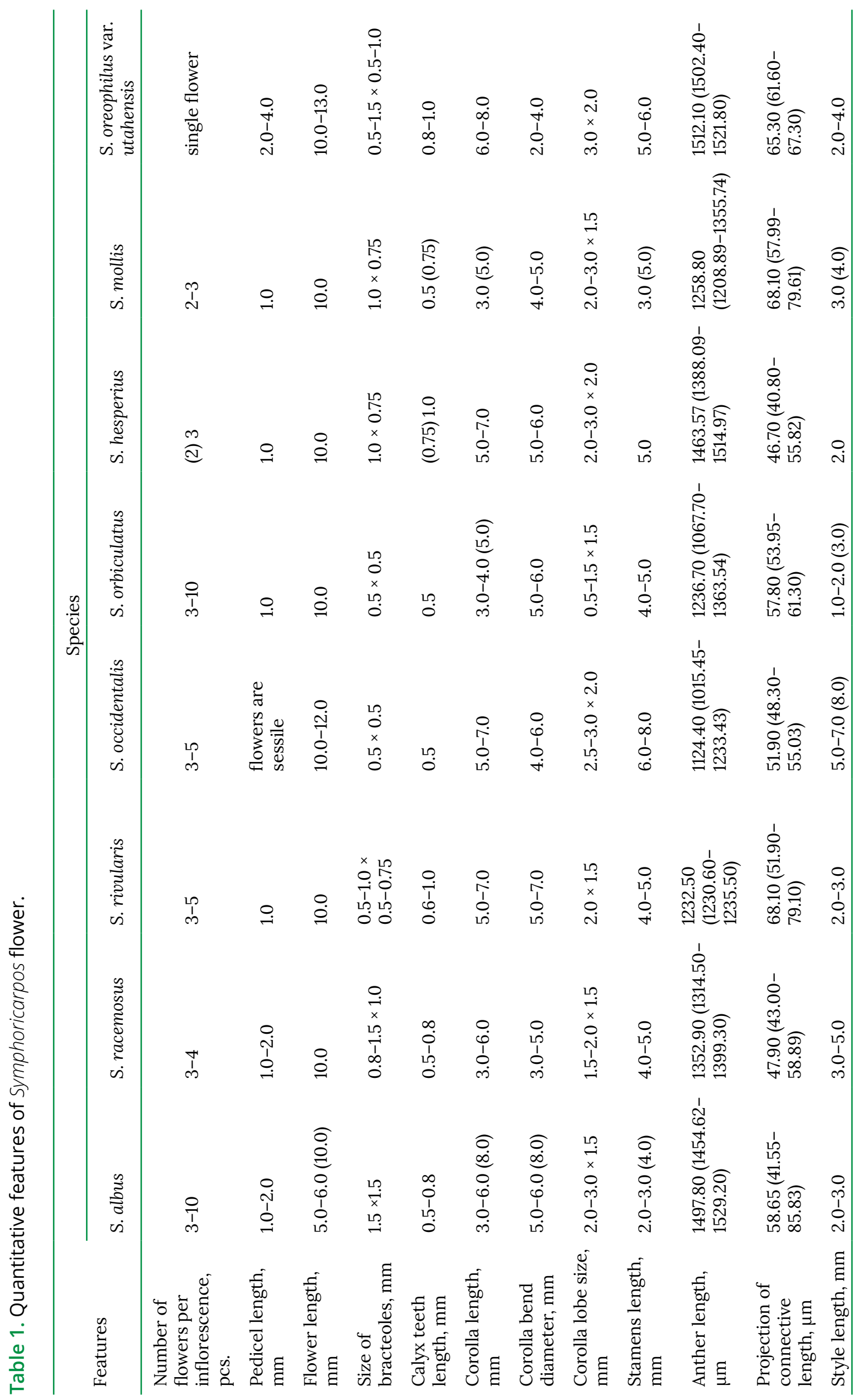




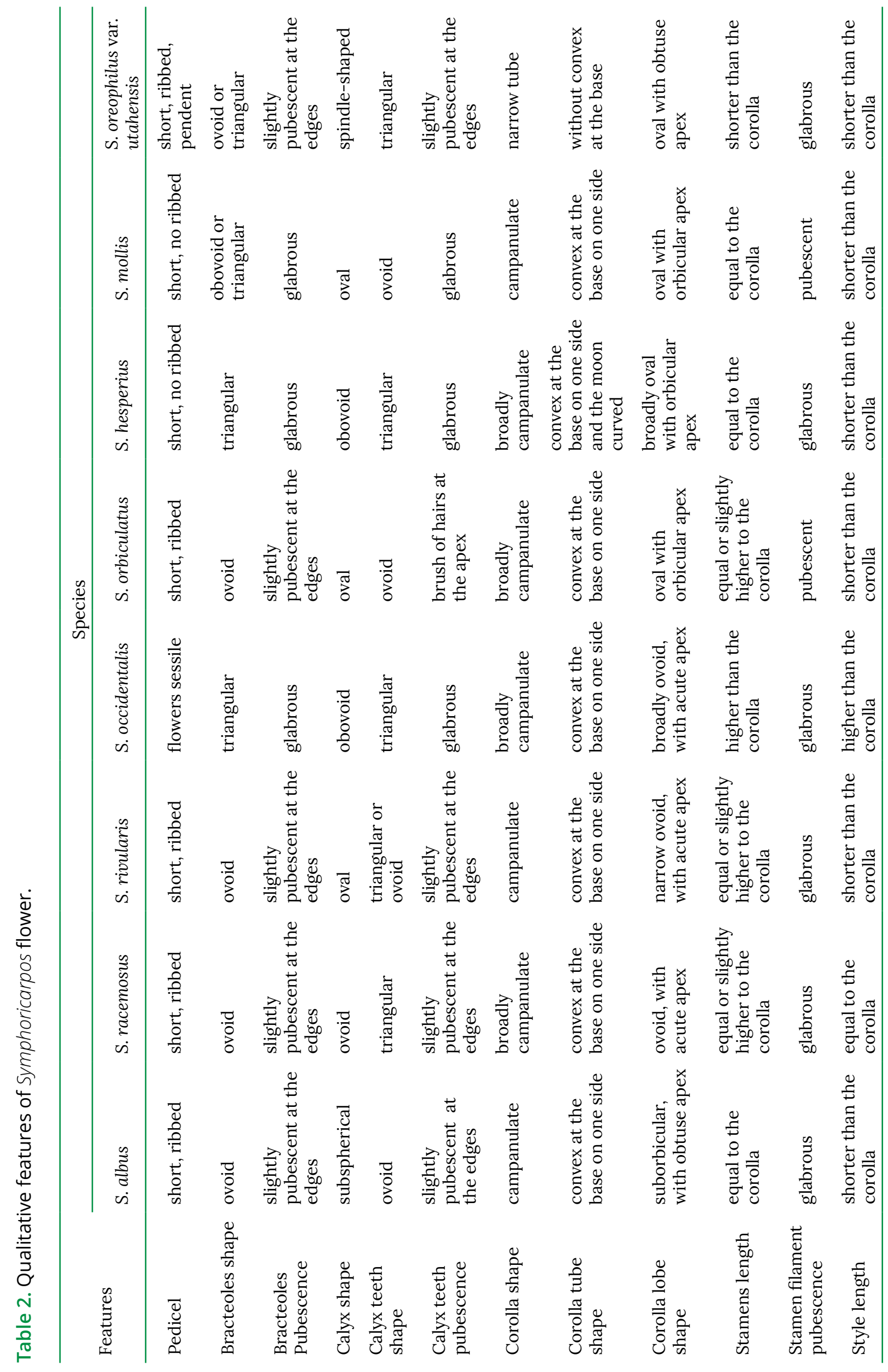



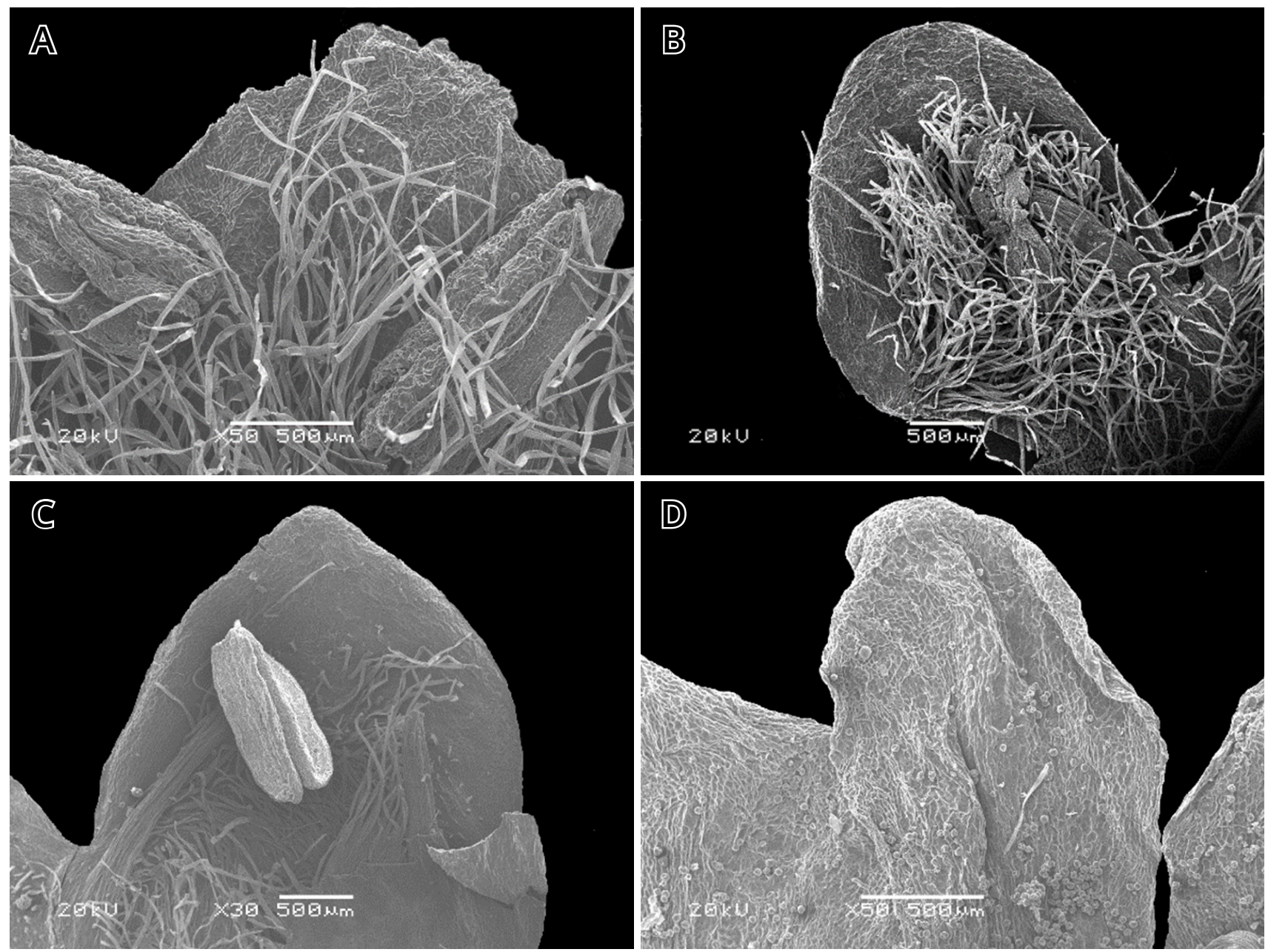

Figure 2. Lobes of the corolla (SEM): A - Symphoricarpos albus (suborbicular, with obtuse apex); B - S. mollis (oval, with orbicular apex); C - S. occidentalis (broadly oval, with acute apex); D - S. oreophilus var. utahensis (oval, with obtuse apex).

$1 / 2$ of the corolla length. We noted that the stamens and style exceed the corolla in length exclusively in S. occidentalis, hence it can be a diagnostic feature of this species (Tables $1 \& 2$ ).

The following differences for other two similar species (S. hesperius and S. mollis) were found. The flowers of S. hesperius are with triangular calyx teeth, broadly bellshaped, and with a longer corolla; the tube of the corolla is crescent-shaped at the base; the filaments of stamens are glabrous. The calyx teeth of S. mollis flowers are deltoid; the corolla is campanulate and shorter; the stamen filaments pubescent by ribbon-like hairs.

Symphoricarpos oreophilus var. utahensis presents a peculiar floral morphology that distinguishes it from all the other studied representatives of the genus Symphoricarpos. It has solitary flowers on long (2-4 mm against $1 \mathrm{~mm}$ in other studied species) pendent pedicels, which are densely pubescent by simple bristly and glandular hairs. Other species have numerous flowers organized in racemes and placed on erect, glabrous pedicels. The calyx of S. oreophilus var. utahensis is elongated and spindle-shaped, unlikely to other species. Its corolla is narrowtubular, 2-4 $\mathrm{mm}$ in diameter and is much shorter than the tube. The tube is not convex at the base. The stamens are shorter or rarely of the same size as the corolla (Tables $1 \& 2$ ).

\section{Conclusions}

The micro- and macromorphological peculiarities of the flowers of six Symphoricarpos species introduced to Ukraine were specified. The morphological features of the calyx, corolla, stamens and style allowing distinguishing S. albus, S. hesperius, S. mollis, S. occidentalis, S. orbiculatus, and 

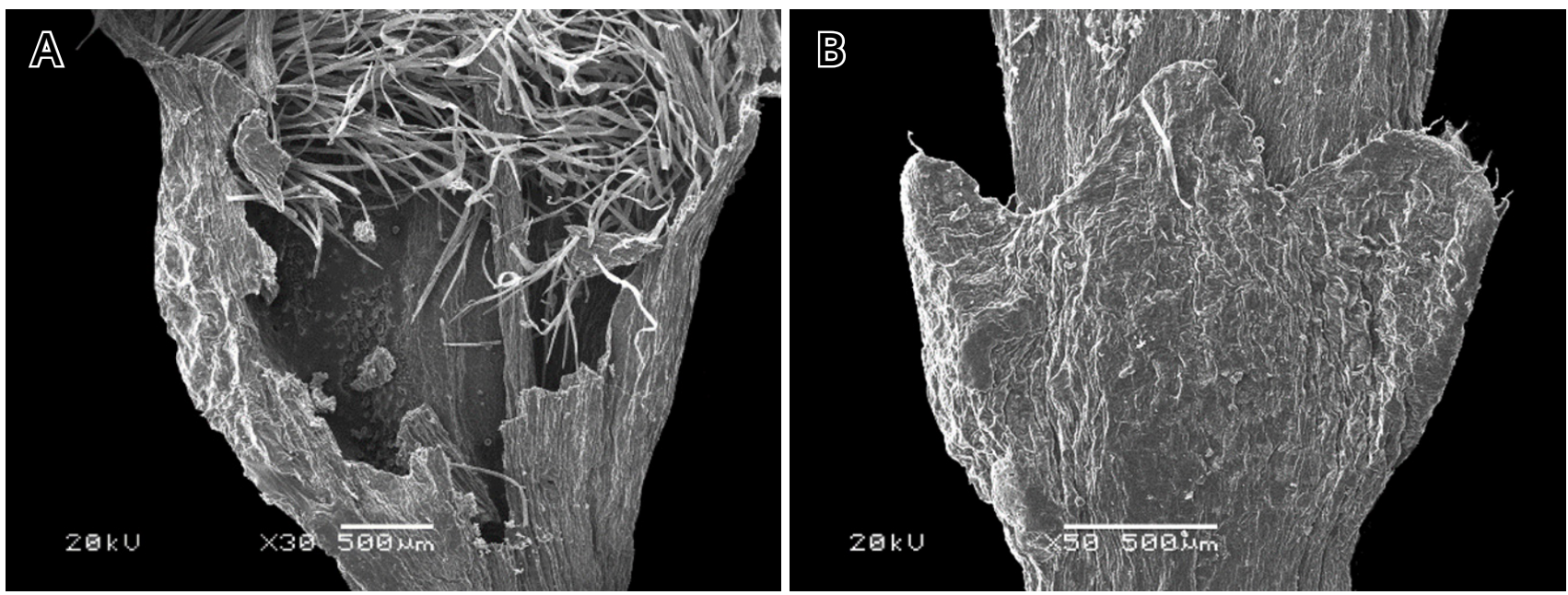

Figure 3. Base of a corolla tube (SEM): A - Symphoricarpos albus (convex at the base of one side); B S. oreophilus var. utahensis (symmetrical, without convexity).
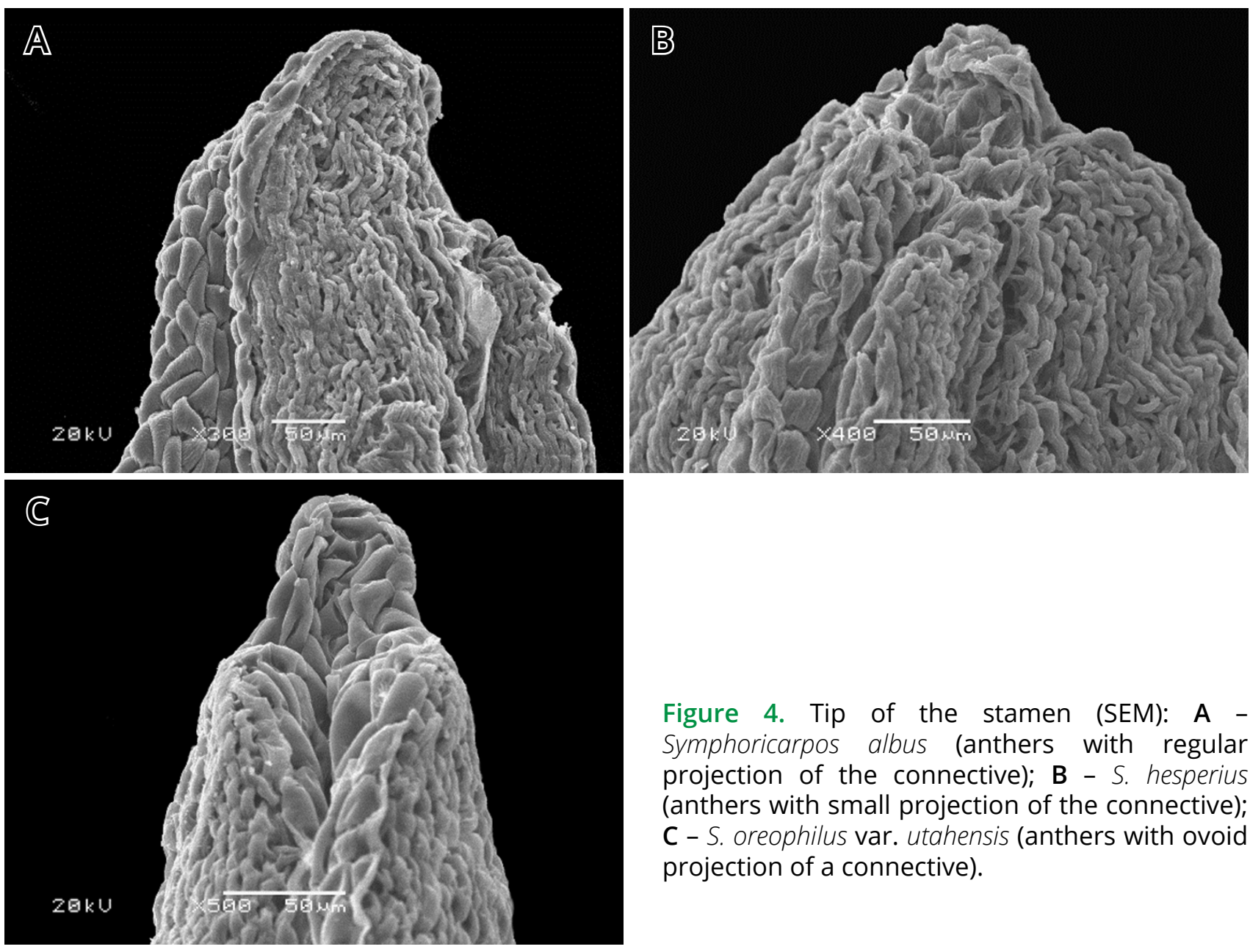

Figure 4. Tip of the stamen (SEM): A Symphoricarpos albus (anthers with regular projection of the connective); B - S. hesperius (anthers with small projection of the connective); C - S. oreophilus var. utahensis (anthers with ovoid projection of a connective).

S. oreophilus var. utahensis were emphasized. These features can be suggested as additional diagnostic treats in the taxonomy of the genus Symphoricarpos. Finaly, the results of our study showed that S. racemosus, S. rivularis, and S. albus share common morphological features of the flower, what supports their current synonymy under the name S. albus. 


\section{References}

Barbarych, A. I. (1961). Caprifoliaceae Juss. In: M. I. Kotov (Ed.), Flora of UkrSSR. Vol. 10 (pp. 249288). Kyiv: Publishing house of the Academy of Sciences of UkrSSR. (In Ukrainian)

Bell, C. D., Edwards, E. J., Kim, S.-T., \& Donoghue, M. J. (2001). Dipsacales phylogeny based on chloroplast DNA sequences. Harvard Papers in Botany, 6(2), 481-499.

Donoghue, M. J., Bell, C. D., \& Winkworth, R. C. (2003). The evolution of reproductive characters in Dipsacales. International Journal of Plant Sciences, 164, 453-464. https://doi.org/10.1086/376874

Evans, K. E. (1974). Symphoricarpos Duham. In: C. S. Schopmeyer (Ed.), Seeds of woody plants in the United States. Agriculture Handbook No. 450 (pp. 787-790). Washington, DC: U.S. Department of Agriculture, Forest Service.

Fedorov, A. A., \& Artiushenko, Z. T. (1975). Atlas on descriptive morphology of higher plants. Flower. Leningrad: Nauka. (In Russian)

Gilbert, O. L. (1995). Symphoricarpos albus (L.) S.F. Blake (S. rivularis Suksd.; S. racemosus Michx). Biological Flora of the British Isles. Journal of Ecology, 83(1), 159-166.

Hauser, A. (2007). Symphoricarpos occidentalis. In: Fire Effects Information System, [Online]. U.S. Department of Agriculture, Forest Service, Rocky Mountain Research Station, Fire Sciences Laboratory (Producer). Retreived from https:// www.fs.fed.us/database/feis/plants/shrub/ symocc/all.html

Hitchcock, C. L., \& Cronquist, A. (1973). Flora of the Pacific Northwest: An illustrated manual. Seattle, London: University of Washington Press.

Howarth, D. G., \& Donoghue, M.J. (2005). Duplications in CYC-like genes from Dipsacales correlate with floral form. International Journal of Plant Sciences, 166(3), 357-370. https://doi.org/10.1086/428634

Kartesz, J. T. (1994). A synonymized checklist of the vascular flora of the United States, Canada, and Greenland. 2nd ed. Portland, Oregon: Timber Press.

Leroy, A., \& Stinchfield Ferris, R. (1960). Symphoticarpos (Dill.) Duhamel. In: R. Stinchfield Ferris (Ed.), An illustrated flora of the Pacific States Washington, Oregon, and California. (Bignoniaceae to Composite). Vol. 4 (pp. 48-50). Stanford, California: Stanford University Press.

McWilliams, J. (2000). Symphoricarpos albus (common snowberry). U.S. Department of Agriculture, Forest Service, Rocky Mountain Research Station, Fire Sciences Laboratory. Retrieved from http://www.fs.fed.us/database/ feis/plants/shrub/symalb/all.html
Moss, E. H. (1983). Symphoricarpos albus. In: E. H. Moss (Ed.), Flora of Alberta. A manual of flowering plants, conifers, ferns, and fern allies found growing without cultivation in the province of Alberta, Canada. 2nd ed. (p. 514). Toronto, Ontario: University of Toronto Press.

Mosyakin, S. L., \& Fedoronhuk, M. M. (1999). Vascular plants of Ukraine. A nomenclatural checklist. Kyiv.

Roels, P., \& Smets, E. (1996). A floral ontogenetic study in Dipsacales. International Journal of Plant Sciences, 157(2), 203-218. https://doi. org/10.1086/297339

Sell, P., \& Murrell, G. (2006). Symphoricarpos. In: Flora of Great Britain and Ireland. 4 (Campanulaceae - Asteraceae) (pp. 41-42). University of Cambridge.

Takhtajan, A. (1997). Diversity and classification offlowering plants. New York: Columbia University Press.

Takhtajan, A. (2009). Flowering Plants. 2nd ed. New York: Springer-Verlag. https://doi. org/10.1007/978-1-4020-9609-9

Theis, N., Donoghue, M. J., \& Li, J. (2008). Phylogenetics of the Caprifolieae and Lonicera (Dipscales) based on nuclear and chloroplast DNA sequences. Systematic Botany, 33(4), 776-783. https://doi.org/10.1600/036364408786500163

Tsymbaliuk, Z.M., Tsarenko, O.M., Dremliuha, N.H., Bulakh, O. V., \& Nytsenko, L. M. (2018). Morphological peculiarities of generative organs of Linnaea borealis L. Chornomors'ki Botanical Journal, 14(1), 32-34. (In Ukrainian). https://www. doi.org/10.14255/2308-9628/18.141/3

Welsh, S. L., Atwood, N. D., Higgins, L. C., \& Goodrich, S. (1987). Symphoricarpos. In: A Utah flora. The Great Basin Naturalist Memoirs No. 9, (pp. 100-101). Provo, Utah: Brigham Young University Press. Retrieved from https:// scholarsarchive.byu.edu/gbnm/vol9/iss1/17

Welsh, S. L., Atwood, N. D., Higgins, L. C., \& Goodrich, S. (1993). Symphoricarpos. In: A Utah flora. 2nd ed. (pp. 110-111). Provo, Utah: Brigham Young University Press.

Wood, B. W. (1965). Revision of Symphoricarpos (Caprifoliaceae). Utah Academy of Sciences, Arts, \& Letters, 42(2), 203-213.

Yang, Q., Landrein, S., Osborne, J., \& Borosova, R. (2011). Caprifoliaceae. In: Z. Y. Wu, P. H. Raven, \& D. Y. Hong(Eds.), Flora of China. Vol. 19. Cucurbitaceae through Valerianaceae, with Annonaceae and Berberidaceae (pp. 616-641). Beijing: Science Press and St. Louis: Missouri Botanical Garden Press.

Zhang, W.-H., Chen, Z.-D., Li, J.-H., Chen, H.-B., and \& Tang, Y.-C. (2003). Phylogeny of the Dipsacales s.l. based on chloroplast trnL-F and $n d h \mathrm{~F}$ sequences. Molecular Phylogenetics and Evolution, 26(2), 176-189. https://doi.org/10.1016/S1055-7903(02)00303-2 
Zyman, S. M., Hrodzynskyi, D. M., \& Bulakh, O. V. Zyman, S. M., Mosiakin, S. L., Bulakh, O. V., (2011). Latin-English-Russian-Ukrainian dictionary of terms on the morphology and the taxonomy of vascular plants. Kyiv: Naukova Dumka. (In Ukrainian) Tsarenko, O. M., \& Felbaba-Klushina, L. M. (2004). Illustrated reference book on the morphology of flowering plants. Uzhgorod: Medium. (In Ukrainian)

\section{Морфологічні особливості квітки видів роду Symphoricarpos (Caprifoliaceae), інтродукованих в Україні}

Олена Булах

Інститут ботаніки імені М.Г. Холодного НАН України, вул. Терещенківська, 2, Київ, 01004; Україна; anemone@ukr.net

За допомогою світлової та сканувальної електронної мікроскопії вивчено будову суцвіття і квіток шести видів роду Symphoricarpos, інтродукованих в Україні. Виявлено морфологічні особливості чашечки, віночка, тичинок і стовпчика маточки, за якими розрізняються квітки видів S. albus (включно з S. racemosus та S. rivularis), S. hesperius, S. mollis, S. occidentalis, S. orbiculatus та S. oreophilus var. utahensis. Отримані дані важливі для ідентифікації видів і таксономії роду Symphoricarpos. Зокрема, результати наших досліджень показали, що квітки S. racemosus, S. rivularis та S. albus мають спільні риси будови, що підтверджує доцільність зведення їх у синоніми під назвою S. albus. В той час, як інші види роду Symphoricarpos демонструють відмінності в будові їх квітки.

Серед ознак відсутніх у доступних літературних джерелах, як додаткові ознаки для ідентифікації інтродукованих в Україну видів роду Symphoricarpos ми пропонуємо такі: кількість квіток у суцвітті, особливості морфології квітконіжки, форма й особливості опушення приквіток, форма зубчиків чашечки та наявність чи відсутність їхнього опушення, наявність чи відсутність опуклості трубочки віночка, наявність яйцеподібного виступу в'язальця над пиляками та загалом розміри всіх елементів квітки.

Також слід відмітити, що з-поміж досліджених видів найбільше відрізняється S. oreophilus var. utahensis, що має поодинокі квітки, розташовані в пазухах листків на пониклих опушених квітконіжках, видовжену веретеноподібну чашечку, вузькотрубчастий, без опуклості при основі віночок, а також коротші за трубочку віночка або, рідше, однакової довжини тичинки з чітким яйцеподібним виступом в'язальця на верхівці. 